\title{
A STATISTICAL ANALYSIS OF WOMEN'S REPRODUCTIVE HEALTH CHARACTERISTICS AFTER INEFFECTIVE REATTEMPTS OF USING ART
}

DOI: $10.36740 /$ WLek202104124

\author{
Tamara H. Romanenko', Anastasiia D. Haiduk', Svetlana V. Turbanist ${ }^{2}$ \\ 'SHUPYK NATIONAL MEDICAL ACADEMY OF POSTGRADUATE EDUCATION OF THE MINISTRY OF HEALTH OF UKRAINE, KYIV, UKRAINE \\ ${ }^{2}$ ISIDA-IVF MEDICAL CENTER LLC, KYIV, UKRAINE
}

\begin{abstract}
The aim: To carry out a statistical analysis of physical and reproductive health characteristics in women after ineffective reattempts of using assisted reproductive technologies and identify significant medical and social factors contributing to the development of chronic endometritis.

Materials and methods: We carried out a statistical analysis involving 177 outpatient medical records: group 1 includes 127 women aged under 45 with two or more ineffective attempts of in vitro fertilization; group 2 comprised 50 healthy women without reproductive disorders. The complete physical exam included past history, clinical and gynecologic examination, lab techniques and medical imaging according to outpatient medical records obtained during the follow-up care in Isida-IVF Medical Center LLC. Chronic endometritis was recognized by means of histologic examination of endometrium, with the samples obtained by an endometrial pipelle biopsy on day 4-9 of the menstrual cycle.

Results: The prevalence of pelvic inflammatory disease in patients of group 1 comprised $47.2 \%$, endometritis $-41.7 \%$; $1.2<0.01$. The prevalence of acute endometritis among patients of group 1 comprised 6.3\%; p1.2 $>0.05$ and was associated with an infection after abortion. In group 1, sexually transmitted infections were reported in $67.7 \%$ of patients, p1.2>0.05, bacterial vaginosis was registered 1.5 times more often $-28.4 \% ; p 1.2<0.05$. In group 1 , single induced abortion was reported in $15.0 \%$, while 2 times it took place in $15.7 \%$ (p1.2 <0.05). Laparoscopies were previously performed in $59.8 \%$ of women, laparotomies - in $62.2 \%$, while in $25.4 \%$ of women these interventions were reperformed. Unilateral salpingectomy, due to ectopic pregnancy, was performed in $25.4 \%$ of women, bilateral - in $12.7 \%$. Fallopian tube removal, due to sactosalpinx, was performed in $25.4 \%$ of women, unilateral salpingectomy took place in $3.9 \%$ of cases. The most significant risk factors of chronic endometritis in groups studied are acute postabortal endometritis, $R R$ (relative risk) $=1.439, p=0.029$ and postoperative peritonitis provoked by the complications of appendectomy, RR $=1.430, p=0.084$. We detected none of significant effects of pelvic inflammatory disease on the development of chronic endometritis ( $R R=45.132$, Confidence interval (CI) (6.151-331.167), $p=0.001)$. The analysis of reproductive failures, as a risk factor of chronic endometritis in women of group 1, showed a significant relative risk: with the past history of premature birth, $R R=$ $1.44, p=0.039$, in case of reattempts of induced abortions, $R R=1.5, p<0.001$, Spontaneous miscarriage $R R=1.572, p=0.001$. A higher relative risk of developing chronic endometritis was observed during pregnancy $-R R=1.597, p=0.001$.

Conclusions: Statistical analysis of women's reproductive health after ineffective reattempts of using ART revealed that the high rate of fetal interventions, Iow rate of alternative and safe abortion methods are registered in these women, as well as the nonavailability of any system of health measures after reproductive failures. A significant increase in miscarriage at early stages takes place, as well as the absence of a tendency for preterm labor to decrease in the rate. Maintaining women's reproductive health is a considerable medical and social issue, whose resolving depends on joint efforts of governmental and public entities, healthcare agencies and the population responsibility for own health. Designing and adopting the program of preconception care and planning for pregnancy in women after ineffective reattempts of using ART, with chronic endometritis as a primary disease, should be the top priority area of a health care system.
\end{abstract}

KEY WORDS: assisted reproductive technologies, chronic endometritis, fertilization failure, reproductive health, pregnancy

Wiad Lek. 2021;74(4):940-947

\section{INTRODUCTION}

The matter of pelvic inflammatory disease these days remains a topical medical and social issue. Pelvic inflammatory disease keeps on being one of the leading causes of reproductive disorders. Along with the high prevalence of cervicitis, vaginitis, salpingo-oophoritis, which occurred, the prevalence of chronic endometritis also rose recently. According to various researchers, the occurrence of chronic endometritis averages out at 14 to $25 \%$ of cases. Typically, chronic endometritis is recognized in women with common miscarriage and comprises $6087.5 \%$ of cases [1-3].

When using intrauterine contraceptive device the prevalence of chronic endometritis is $6-8 \%$ and increases threefold, if such contraception is used longer than five years. The prevalence of chronic endometritis in women, who have repeatedly undergone dilation and curettage for the reason of induced abortion or stillbirth, reaches $12.525 \%$ of cases $[4,5]$.

Chronic endometritis is an inflammatory disease, which is characterized by the impairment of endometrial structure and function, as well as predominantly early pregnancy loss: stillbirth, missed miscarriage, infertility, ineffective attempts of in vitro fertilization and embryo transfer, as well as pregnancy and postpartum complications $[2,3]$. 
Table I. Marital status in women examined (abs. n. \%)

\begin{tabular}{|c|c|c|c|}
\hline \multirow[b]{2}{*}{ Parameter } & \multicolumn{2}{|c|}{ Groups } & \multirow{2}{*}{$\begin{array}{l}\text { Statistical significance of } \\
\text { differences }\end{array}$} \\
\hline & $\begin{array}{c}1 \\
n=127\end{array}$ & $\begin{array}{c}2 \\
n=50\end{array}$ & \\
\hline First marriage & $91(71.6 \%)$ & $37(74 \%)$ & $p>0.05$ \\
\hline Second marriage & $9(7.1 \%)$ & $13(26 \%)$ & $p>0.05$ \\
\hline Registered marriage & $100(78.7 \%)$ & $39(78 \%)$ & $p>0.05$ \\
\hline Common-law marriage & $27(21.3 \%)$ & $11(22 \%)$ & $p>0.05$ \\
\hline
\end{tabular}

Note: $p<0.05$ - statistical significance of differences between groups 1 and 2 .

The persistence of infection in endometrium in chronic endometritis, even without prominent disease symptoms, results in the damage to the receptor system in endometrium that may be one of the causes of reproductive disorders in women with intact hormonal ovarian function $[4,6-9]$.

It is known that risk factors of chronic endometritis are all invasive interventions in the uterine cavity, infection and inflammation as complications after delivery and abortion, intrauterine contraceptive device, vaginitis and cervicitis, cervical stenosis, uterine malformations [10-13]. The primary chronic disease process, involving endometrium in patients having disorders of local immunity [1] with secondary immunodeficiency as a primary disease that occurred due to urogenital infection, cannot be excluded. Despite the adoption of modern technologies for diagnostics and exploration of the brand-new treatment methods, the prevalence of chronic endometritis is not reduced that motivates to explore new approaches to prevention and detection of risk factors.

\section{THE AIM}

The aim - to carry out a statistical analysis of physical and reproductive health characteristics in women after ineffective reattempts of using assisted reproductive technologies and identify significant medical and social factors contributing to the development of chronic endometritis.

\section{MATERIALS AND METHODS}

We carried out a statistical analysis involving outpatient medical records of 127 women aged under 45 with two or more ineffective attempts of using in vitro fertilization (group1). Inclusion criteria: women's childbearing age - 25-45 years; uterine factor infertility; regular sex life without using contraception for 1 year and more; male fertility. Exclusion criteria: endocrine, tuboperitoneal and/ or combined infertility, exacerbation of a chronic physical disorder, subcompensations and decompensations during the last year.

The comparison group (group 2) comprised 50 healthy women without reproductive disorders. To exclude other causes of reproductive disorders, women with severe physical and allergic disorders were excluded, as well as patients with endocrine factor in reproductive disorder, with systemic diseases, congenital thrombophilia, antiphospholipid syndrome, pelvic inflammatory disease in particular; patients, who took immunomodulators less than 6 months ago. The complete physical exam included past history, clinical and gynecologic examination, lab techniques and medical imaging according to outpatient medical records obtained during the follow-up care in Isida-IVF Medical Center LLC. Chronic endometritis was recognized by means of histologic examination of endometrium, with the samples obtained by an endometrial pipelle biopsy on day 4-9 of the menstrual cycle. The techniques for mathematical statistics represented in STATISTICA 6.1 Statsoft Inc were applied in the study, the statistical significance of differences was assessed by the relative risk (RR) value using the following formula: $\mathrm{RR}=$ $\mathrm{AxD} / \mathrm{BxC}$, where $\mathrm{A}$ means the number of patients from the group with chronic endometritis who also represent the feature studied; $\mathrm{C}$ - do not have the same characteristic value; $\mathrm{B}$ - the number of patients in the control group, who have the feature studied; $\mathrm{D}$ - do not have the same feature. To prove that the differences observed between $\mathrm{AD}$ and $\mathrm{BC}$ are not accidental, the $\chi^{2}$ criterion was used in the table and for one degree of freedom.

\section{RESULTS}

When estimating the age, the mean age of those examined was found to be significantly $(\mathrm{p}<0.05)$ higher in group 1 and comprised $35.17 \pm 0.42$, in group 2 this value was $28.30 \pm$ 0.71 years. Group 1 numbered $72(56.7 \%)$ of women of early reproductive age among the patients with ineffective attempts of using ART, 55 (43.3\%) of those examined were of late reproductive age. This values came to 47 (94.0\%) and $3(6.0 \%)$, respectively, in group 2 .

The tendency to later pregnancy planning is registered in patients of group 2. Women of late reproductive age postponed childbearing with an eye on career growth and had a high standard of living. Woman's marital status is a crucial social factor that determines childbearing. The high frequency of marriages registered first-ever was reported in all groups (Table I).

In group I, irrespective of reproductive loss (ectopic pregnancy and missed miscarriage) and infertility, marriages did not break up, while spouses applied for a pre-pregnancy checkup and selection of the method of pregnancy planning. The frequency of unregistered marriages in groups studied did not have any statistically significant differences and came at $27(21.3 \%)$ in group 1, $101(22.0 \%)$ cases in group 2. 
Table II. Menstrual cycle characteristics in women examined $(M \pm m)$

\begin{tabular}{cccc}
\hline Parameters & \multicolumn{2}{c}{ Groups } & Statistical significance of \\
\cline { 2 - 4 } & $\begin{array}{c}\mathbf{1} \\
\mathbf{n}=\mathbf{1 2 7}\end{array}$ & $\begin{array}{c}\mathbf{2} \\
\mathbf{n}=\mathbf{5 0}\end{array}$ & $\mathrm{p}>0.05$ \\
\hline Mean age of menarche & $13.3 \pm 0.1$ & $13.1 \pm 0.1$ & $\mathrm{p}>0.05$ \\
\hline Average duration of menses & $5.4 \pm 0.1$ & $4.8 \pm 0.1$ & $\mathrm{p}>0.05$ \\
\hline Average duration of the period & $29.3 \pm 0.2$ & $28.2 \pm 0.1$ & \\
\hline
\end{tabular}

Note: $p<0.05-$ statistical significance of differences between groups 1 and 2 .

\section{Infertility structure in group 1}

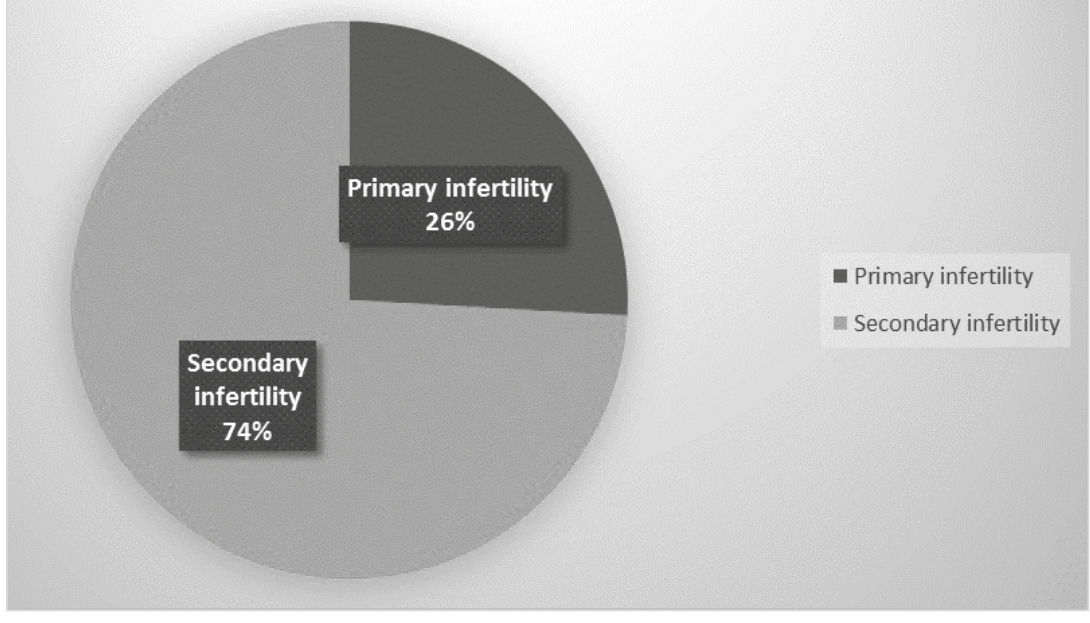

Fig 1. Infertility structure in women of group 1.
When studying women's reproductive health in target groups, we assessed menstrual cycle characteristics, the age of sexual onset, parity. The analysis of menstrual cycle characteristics indicated the age variation at menarche ranging from 11 to 16, depending on the groups it averaged out at $13.3 \pm 0.1$ and $13.1 \pm 0.1$ years, respectively (Table II).

Early menarche (11-12 years) was more likely to be registered in patients of group 1 in $27.5 \%$ of cases in contrast to $20.0 \%$ in group $2(\mathrm{p}<0.05)$. We did not obtain any statistically significant differences $(\mathrm{p}>0.05)$ among patients of groups studied according to the duration of a period and menstrual cycle. The age of menarche corresponds to patients' normal sexual development, while the duration of a period and menstrual cycle complied with characteristics of a normal menstrual cycle. Gonadotropin and steroid evaluation combined with an ultrasound-based monitoring of preovulatory follicle growth indicated the biphasic ovulatory type menstrual cycle in all women from groups studied. Sexual behavior of modern women is characterized by early sexual onset, multiple sex partners. The age of the first pregnancy is 17-18 years, the age of the first childbirth is 25-28 years, over the whole reproductive period woman delivers one-two children. Women and families, willing to have children, reduce in number. Statistically significant differences in the age of sexual onset between patients of group $1-17.8 \pm 0.2$ years and group 2 , where this value comprised $18.9 \pm 0.3$ years $(\mathrm{p}<0.05)$ were obtained in the study (TableIII). Every third patient of group 1 (30.7\%) had two and more sex partners, $20 \%$ of women in control group had 2 sex partners that did not make any statistically significant differences.

The age of the first pregnancy in patients of group 1 (excluding women with primary infertility) was $22.5 \pm 0.4$ years in such a case, the age of the first delivery was $22.8 \pm 0.7$ years that indicates the high frequency of delivery resulting from the first pregnancy and the prevalence of secondary infertility. In primary infertility the mean age of sexual onset was $17.3 \pm 0.6$ years. All women of group 1 complained about reproductive dysfunction. Primary infertility came to $33(25.9 \%)$, secondary - $94(74.1 \%)$ in the structure of reproductive disorders in patients of group 1 . Data on the structure of reproductive disorders in women after ineffective attempts of using ART are illustrated in Fig. 1.

The majority of patients from group 1, or $69(54.4 \%)$, applied for a treatment after 5 and more years of infertility. Seventy-eight (61.4\%) women applied for the $3^{\text {rd }}$ try of in vitro fertilization, $40(31.5 \%)$-for the $4^{\text {th }}$ and $9(7.1 \%)-$ for the $5^{\text {th }}$, and at the same time all patients with primary infertility had failures at trying in vitro fertilization.

Over the last years an increase in the prevalence of reproductive system diseases in women of various ages has become exponential. The structure analysis of gynecological morbidity (Table IV) indicated the high rate of benign diseases and pelvic inflammatory disease.

Typically, patients of group 1 numbered 60 (47.2\%) complained about the past history of salpingo-oophoritis, $53(41.7 \%)$ - endometritis, the incidence of acute endometritis among patients of group 1 comprised 8 (6.3\%) and 
Table III. Features of sexual behavior $(\mathrm{M} \pm \mathrm{m})$

\begin{tabular}{cccc} 
Parameter & \multicolumn{2}{c}{ Groups } & Statistical significance \\
of differences & $\mathbf{2}$ & $\mathbf{n}=\mathbf{5 0}$ & $\mathrm{p}<0.05$ \\
\cline { 2 - 4 } & $\mathbf{n}=\mathbf{1 2 7}$ & $18.9 \pm 0.3$ & $\mathrm{p}<0.05$ \\
\hline Mean age of sexual onset & $17.8 \pm 0.2$ & $25.4 \pm 0.6$ & $\mathrm{p}<0.05$ \\
\hline Mean age of the first pregnancy & $22.5 \pm 0.4$ & $26.2 \pm 0.5$ & $\mathrm{p}<0.05$ \\
\hline Mean age at first birth & $22.8 \pm 0.7$ & $1.2 \pm 0.1$ & $2.4 \pm 0.2$ \\
\hline
\end{tabular}

Note: $p<0.05$ - statistical significance of differences between groups 1 and 2 .

Table IV. Gynecological morbidity in women examined (abs. n. \%)

\begin{tabular}{|c|c|c|c|}
\hline \multirow[b]{2}{*}{ Parameter } & \multicolumn{2}{|c|}{ Groups } & \multirow{2}{*}{$\begin{array}{c}\text { Statistical significance } \\
\text { of differences }\end{array}$} \\
\hline & $\begin{array}{c}1 \\
n=127\end{array}$ & $\begin{array}{c}2 \\
n=50\end{array}$ & \\
\hline Benign cervical disorders & $72(56.7 \%)$ & $18(36 \%)$ & $\mathrm{p}<0.05$ \\
\hline Benign ovarian tumors & $14(11 \%)$ & $2(4 \%)$ & $\mathrm{p}<0.05$ \\
\hline Salpingo-oophoritis & $60(47.2 \%)$ & $(0 \%)$ & $\mathrm{p}<0.001$ \\
\hline Endometritis & $53(41.7 \%)$ & $(0 \%)$ & $\mathrm{p}<0.001$ \\
\hline Endometrial hyperplasia & $10(7.9 \%)$ & $(0 \%)$ & $\mathrm{p}<0.05$ \\
\hline Infertility (I) & $33(25.9 \%)$ & $(0 \%)$ & \\
\hline Infertility (II) & $94(74.1 \%)$ & $(0 \%)$ & - \\
\hline BV & $36(28.4 \%)$ & $9(18 \%)$ & $\mathrm{p}<0.05$ \\
\hline STIs & $86(67.7 \%)$ & $8(16 \%)$ & $\mathrm{p}<0.05$ \\
\hline
\end{tabular}

Note: $p<0.05, p<0.001-$ statistical significance of differences between groups 1 and 2 .

Table V. The assessment of risk factors of chronic endometritis in pelvic inflammatory disease (abs. n., \%, $\mathrm{Cl}, \varphi$ )

\begin{tabular}{|c|c|c|c|c|c|c|c|}
\hline \multirow[t]{2}{*}{ Parameter } & \multicolumn{2}{|c|}{$\begin{array}{c}\text { Group } 1 \\
n=127\end{array}$} & \multicolumn{2}{|c|}{$\begin{array}{c}\text { Group } 2 \\
n=50\end{array}$} & \multirow[t]{2}{*}{$\mathbf{P}^{*}$} & \multirow[t]{2}{*}{$\begin{array}{c}\text { OP } \\
\text { (Cl 95\%) }\end{array}$} & \multirow[t]{2}{*}{$\begin{array}{l}\text { Strength of the } \\
\text { association } \\
(\varphi)\end{array}$} \\
\hline & abs. & $\%$ & abs. & $\%$ & & & \\
\hline $\begin{array}{c}\text { Acute postabortal } \\
\text { endometritis }\end{array}$ & \multicolumn{2}{|c|}{$8(6.3 \%)$} & \multicolumn{2}{|c|}{$(0 \%)$} & 0.029 & $\begin{array}{c}1.439 \\
(1.330-1.557) \\
\end{array}$ & $\begin{array}{c}0.130 \\
p=0.029\end{array}$ \\
\hline Salpingo-oophoritis & \multicolumn{2}{|c|}{$43(33.9 \%)$} & \multicolumn{2}{|c|}{$(0 \%)$} & 0.001 & $\begin{array}{c}45.132 \\
(6.151-31.167)\end{array}$ & $\begin{array}{c}0.358 \\
p=0.001\end{array}$ \\
\hline Postoperative peritonitis & \multicolumn{2}{|c|}{$4(3.2 \%)$} & \multicolumn{2}{|c|}{$(0 \%)$} & 0.084 & $\begin{array}{c}1.430 \\
(1.324-1.545)\end{array}$ & $\begin{array}{c}0.103 \\
p=0.08)\end{array}$ \\
\hline
\end{tabular}

Note: $\mathrm{p}^{*}$ - statistical significance of differences between groups 1 and 2 .

was associated with postabortal infection. Benign cervical disorders prevailed over pelvic inflammatory disease except for the value in the control group. Predominance of their frequency was reported in patients of group $1-72(56.7 \%)$, which is significantly more often $(\mathrm{p}<0.01)$ comparing to group $2-18(36.0 \%)$. All patients of group 1 took medication (curative treatment with subsequent recovery of normal vaginal flora) and different techniques of radical cervical surgery. Radical techniques for treating cervical ectropion after delivery were used in $8(16.0 \%)$ women of group 2 and they had normal structure and function of cervix till the moment of their inclusion in the study. The occurrence of functional ovarian cysts and ovarian tumors did not make any statistically significant differences in groups, but prevailed slightly in patients of group $1-14$
(11.0\%), which is three times more frequent as compared to group $2-2(4.0 \%)(\mathrm{p}<0.05)$.

In order to assess risk factors of chronic endometritis in patients of group 1, multiple factor analysis with subsequent determination of relative risk and the strength of the association was carried out. The most significant risk factors of chronic endometritis in groups studied were acute postabortal endometritis, $R R=1.439, \mathrm{p}=0.029$ and postoperative peritonitis, resulting from complications of appendectomy- $R R=1.430, p=0.084$. At the same time, we did not detect any significant effect of salpingo-oophoritis on chronic endometritis progression- $\mathrm{RR}=45.132$, CI (6.151-331.167), $\mathrm{p}=0.001$ (Table V).

The occurrence of sexually transmitted infections (STIs), dysbiosis, lower genital tract infectious diseases made the 
Table VI. Assessment of risk factors of chronic endometritis depending on an infectious agent (abs. n., \%, Cl, $\varphi$ )

\begin{tabular}{|c|c|c|c|c|c|}
\hline \multirow[t]{2}{*}{ Parameter } & $\begin{array}{c}\text { Group } 1 \\
n=127\end{array}$ & $\underset{n=50}{\text { Group } 2}$ & \multirow[t]{2}{*}{$\mathbf{P}^{*}$} & \multirow[t]{2}{*}{$\begin{array}{c}\text { OP } \\
\text { (CI 95\%) }\end{array}$} & \multirow[t]{2}{*}{$\begin{array}{l}\text { Strength of the } \\
\text { association } \\
(\varphi)\end{array}$} \\
\hline & abs. & abs. & & & \\
\hline Chlamydia infection & $19(15 \%)$ & $3(6 \%)$ & 0.046 & $\begin{array}{c}2.646 \\
(0.987-7.093)\end{array}$ & $\begin{array}{c}0.130 \\
p=0.029\end{array}$ \\
\hline $\begin{array}{l}\text { Ureaplasma urealyticum } \\
\text { infection }\end{array}$ & $29(22.8 \%)$ & $2(4 \%)$ & 0.001 & $\begin{array}{c}5.734 \\
(1.991-6.515)\end{array}$ & $\begin{array}{c}0.358 \\
p=0.001\end{array}$ \\
\hline $\begin{array}{l}\text { Mycoplasma genitalium } \\
\text { (Mgen) infection }\end{array}$ & $20(15.7 \%)$ & $4(8 \%)$ & 0.824 & $\begin{array}{c}1.085 \\
(0.527-2.234)\end{array}$ & $\begin{array}{c}0.103 \\
p=0.08)\end{array}$ \\
\hline
\end{tabular}

Note: $p^{*}$ - statistical significance of differences between groups 1 and 2 .

Table VII. Assessment of risk factors of chronic endometritis that are associated with reproductive history (abs. n., \%, Cl, $\varphi$ )

\begin{tabular}{|c|c|c|c|c|c|}
\hline \multirow[t]{2}{*}{ Parameter } & $\begin{array}{c}\text { Group } 1 \\
n=127\end{array}$ & $\begin{array}{c}\text { Group } 2 \\
n=50\end{array}$ & \multirow[t]{2}{*}{$\mathbf{P}^{*}$} & \multirow[t]{2}{*}{$\begin{array}{c}\text { OP } \\
\text { (Cl 95\%) }\end{array}$} & \multirow[t]{2}{*}{$\begin{array}{c}\text { Strength of the } \\
\text { association } \\
(\varphi)\end{array}$} \\
\hline & abs. & abs. & & & \\
\hline Normal labor & 43 (33.9\%) & $6(12 \%)$ & 0.089 & $\begin{array}{c}1.735 \\
(0.962-3.130)\end{array}$ & $\begin{array}{c}0.110 \\
(p=0.065)\end{array}$ \\
\hline Preterm labor & $9(7.1 \%)$ & $0(0 \%)$ & 0.039 & $\begin{array}{c}1,44 \\
(1.33-1.56)\end{array}$ & $\begin{array}{c}0.141 \\
(p=0.017)\end{array}$ \\
\hline Induced abortion & 47 (37.0\%) & $0(0 \%)$ & 0.01 & $\begin{array}{c}0.990 \\
(0.591-1.659)\end{array}$ & $\begin{array}{c}0.450 \\
(p=0.001)\end{array}$ \\
\hline Medical abortion & $0(0.0 \%)$ & $2(4.0 \%)$ & 0.001 & - & - \\
\hline First abortion & 19 (15.0\%) & $2(4.0 \%)$ & 0,163 & $\begin{array}{c}1.841 \\
(0.773-4.388)\end{array}$ & $\begin{array}{c}0.083 \\
(p=0.163)\end{array}$ \\
\hline Repeated abortion & 20 (15.7\%) & $0(0 \%)$ & 0.001 & $\begin{array}{c}1.503 \\
(1.376-1.642)\end{array}$ & $\begin{array}{c}0.242 \\
(p=0.001)\end{array}$ \\
\hline Miscarriage & 29 (22.8\%) & $0(0 \%)$ & 0.001 & $\begin{array}{c}1.572 \\
(1.425-1.735) \\
\end{array}$ & $\begin{array}{c}0.316 \\
(p=0.001) \\
\end{array}$ \\
\hline Missed miscarriage & 37 (29.1\%) & $0(0 \%)$ & 0.001 & $\begin{array}{c}1.597 \\
(1.443-1.768)\end{array}$ & $\begin{array}{c}0.338 \\
(p=0.001)\end{array}$ \\
\hline
\end{tabular}

Note: $p$ - statistical significance of differences

past history distinctive in all patients of group 1. In group 1 STIs were registered in 86 (67.7\%), BV - 36 (28.4\%) (p1.2<0.05), which was fairly more often as opposed to women of group 2: STIs - 8 (16.0\%), BV - $9(18.0 \%)$ cases.

We assessed the effect on CE; typically detected in vaginal bacteria biotope (Table VI).

Parameters of confidence intervals and the strength of the association let us suppose that there is no effect of these bacteria on chronic endometritis that proves the numerous researchers' opinion about the overestimation of infectious agents' contribution to pathogenesis of chronic inflammation of endometrium.

The study of reproductive history of women in target groups revealed the high parity of pregnancies among patients in group 1 with secondary infertility. The average number of pregnancies per 1 patient in group 1 came to 1.6 \pm 0.02 , in group $2-0.3 \pm 0.01$ (p1.2<0.001). We did not get any statistically significant differences in the number of deliveries in women of group 1, and the relative risk of the effect on chronic endometritis turned out to be low, $\mathrm{RR}=1.735,(\mathrm{CI}=0.962-3.130), \mathrm{p}=0.089$.

We analyzed the structure of perinatal loss in the past history of women from group I with the history of secondary infertility. In group 1, miscarriage/stillbirth, intrapartum, early neonatal and infant deaths occurred in normal timely birth and comprised $3.2 \%, 1.1 \%, 2.1 \%$ and $2.1 \%$, respectively. In two cases, miscarriage/stillbirth was recognized as a manifestation of placental insufficiency in case of full-term pregnancy in women, who have previously got abortions. Cases of early neonatal death resulted from intrauterine hypoxia and birth asphyxia. Mortality among infants was due to the effects of birth injuries: one newborn died because of Hypoxic-Ischemic Encephalopathy, one because of sepsis as a complication. Two cases of perinatal death due to congenital malformations took place in group 2 .

The analysis of reproductive history associated with invasive interventions in the uterine cavity in the cohort is as 
Table VIII. Structure of surgical procedures among women examined (abs. n., \%)

\begin{tabular}{|c|c|c|c|}
\hline \multirow[b]{2}{*}{ Parameter } & \multicolumn{2}{|c|}{ Groups } & \multirow{2}{*}{$\begin{array}{l}\text { Statistical significance } \\
\text { of differences }\end{array}$} \\
\hline & $\begin{array}{c}1 \\
n=127\end{array}$ & $\begin{array}{c}2 \\
n=50\end{array}$ & \\
\hline Laparoscopy & $76(59.8 \%)$ & $2(4 \%)$ & $\mathrm{p}<0.001$ \\
\hline Laparotomy & $79(62.2 \%)$ & $1(2 \%)$ & $\mathrm{p}<0.001$ \\
\hline Salpingectomy & $66(52 \%)$ & $(0 \%)$ & $p<0,001$ \\
\hline Salpingo-oophorectomy & $5(3.9 \%)$ & $(0 \%)$ & $\mathrm{p}<0.05$ \\
\hline Ovarian surgery & $14(11 \%)$ & $1(2 \%)$ & $p>0.05$ \\
\hline Appendectomy & $15(11.8 \%)$ & $2(4 \%)$ & $\mathrm{p}<0.05$ \\
\hline Peritonitis & $5(3.9 \%)$ & $(0 \%)$ & $\mathrm{p}<0.05$ \\
\hline Cholecystectomy & $6(4.7 \%)$ & $(0 \%)$ & $p<0.05$ \\
\hline Uterine myomectomy & $8(6.3 \%)$ & $(0 \%)$ & $\mathrm{p}<0.05$ \\
\hline
\end{tabular}

Note: $p<0.05, p<0.001$ - statistical significance of differences between groups 1 and 2 .

Table IX. Assessment of risk factors of chronic endometritis in case pelvic surgery (abs. n., $\%, \mathrm{Cl}, \varphi)$

\begin{tabular}{|c|c|c|c|c|c|}
\hline \multirow[t]{2}{*}{ Parameter } & $\begin{array}{c}\text { Group } 1 \\
n=127\end{array}$ & $\underset{n=50}{\text { Group } 2}$ & \multirow[t]{2}{*}{$\mathbf{P}^{*}$} & \multirow[t]{2}{*}{$\begin{array}{c}\text { OP } \\
\text { (CI 95\%) }\end{array}$} & \multirow[t]{2}{*}{$\begin{array}{l}\text { Strength of the } \\
\text { association } \\
(\varphi)\end{array}$} \\
\hline & abs. & abs. & & & \\
\hline Salpingectomy & 33 (26.0\%) & $0(0 \%)$ & 0.001 & $\begin{array}{c}1.532 \\
(1.397-1.680) \\
\end{array}$ & $\begin{array}{c}0.276 \\
(p=0.001)\end{array}$ \\
\hline $\begin{array}{l}\text { Salpingectomy due to ectopic } \\
\text { pregnancy }\end{array}$ & $\begin{array}{c}22 \\
(17.3 \%)\end{array}$ & $0(0 \%)$ & 0,001 & $\begin{array}{c}1.500 \\
(0.962-3.130)\end{array}$ & $\begin{array}{c}0.110 \\
(p=0.065)\end{array}$ \\
\hline $\begin{array}{l}\text { Salpingectomy due to } \\
\text { sactosalpinx }\end{array}$ & 11 (8.7\%) & $0(0 \%)$ & 0.005 & $\begin{array}{c}1.503 \\
(1.374-1.638)\end{array}$ & $\begin{array}{c}0.238 \\
(p=0.001)\end{array}$ \\
\hline
\end{tabular}

Note: $p$ - statistical significance of differences

follows: the number of induced abortions in women of group 1 turned out to be as follows: single induced abortion was reported in $19(15 \%), 2$ times it took place in $20(15.7 \%)$, numerous abortions - $10(7.8 \%)(\mathrm{p} 1.2<0.05)$, miscarriage 29 cases $(22.8 \%)$ and missed miscarriage - 37 cases $(29.1 \%)$.

We comprehensively characterized risk factors of chronic endometritis and reproductive failures by means of statistically significant differences, OR and the strength of the association (Table VII). When studying sexual behavior and early pregnancy failure in target groups we identified risk factors that provoke $\mathrm{CE}$. While identifying risk factors of chronic endometritis we obtained the following results: past history of premature birth, $R R=1.44, p<0.039$. The most significant risks were reported in repeated abortions$\mathrm{RR}=1.503, \mathrm{p}<0.001 ;$ miscarriage $-\mathrm{RR}=1.572, \mathrm{p}<0.001$. Higher relative risk of chronic endometritis was observed in missed miscarriage $-\mathrm{RR}=1.597, \mathrm{p}<0.001$.

Data on the number of surgical procedures in women with different variants of reproductive loss are represented in Table VIII. The frequency of pelvic and abdominal surgery appeared to be reliably higher in group, at the same time laparoscopy was performed in 76 (59.8\%), laparotomy - in $79(62.2 \%)$ and in every fifth woman $27.9 \%$ of surgical procedures were reperformed, the average number of surgical procedures per 1 patient was $1.2 \pm 0.06$.
The frequency of surgical procedures is 6 times lower in control group, laparotomy prevailed, the average number of surgical procedures per 1 patient was $0.2 \pm 0.01$.

It is worth mentioning that the frequency of fallopian tube procedures was higher in group 1. Unilateral salpingectomy for the reason of ectopic pregnancy was performed in every fifth patient $-25.4 \%$, bilateral - in every tenth woman $(12.7 \%)$. Salpingectomy for the reason of sactosalpinx was performed in every fifth woman $-25.4 \%$, unilateral salpingectomy took place in $3.9 \%$ of patients. The frequency of ovarian laparoscopic surgery (cystic degeneration was an indication for ovarian wedge resection) came up to $11.0 \%, 2.0 \%$ had resection due to a ruptured corpus luteum cyst in control group. It is noteworthy that laparotomy and laparoscopy were used equally in all groups that indicated the insufficient use of endoscopic technologies when providing gynecological urgent care (Table IX).

Thus, statistical analysis of women's reproductive health after ineffective reattempts of using ART revealed that the high rate of fetal interventions, low rate of alternative and safe abortion methods are registered, as well as the nonavailability of any system of health measures after reproductive failures. A significant increase in miscarriage at early stages takes place, as well as the absence of a tendency for preterm labor to decrease in the rate. 


\section{DISCUSSION}

To implement the objectives of our study, we assessed women's reproductive health in target groups, analyzed risk factors of reproductive failures and chronic endometritis during the preconception period (stage 1 of the study). Based on the analysis of risk factors for reproductive failures and chronic endometritis during the preconception period (stage 1 of the study) it was identified that the risk of reproductive failures is determined by:

1) Nonavailability of a well-defined system for pregnancy planning and low coverage of the female cohort with modern contraception methods that contribute to high prevalence of benign ovarian tumors and ectopic pregnancy, observed in patients of group 1. Ectopic pregnancy prevailed in group 1: it was reported once in 35 patients $(27.5 \%)$, twice - in $17(13.4 \%), 3$ times - in $2(1.6 \%(\mathrm{p} 1.2<0.001))$.

2) The high occurrence of salpingo-oophoritis in patients of group $1-47.2 \%$, endometritis $-41.7 \%$ p $1.2<0.01$. The frequency of acute endometritis among patients of group 1 comprised $8(6.3 \%$ (p1.2>0.05) and resulted from postabortal infection.

3) The occurrence of Sexually transmitted infections, dysbiosis and lower genital tract infectious diseases, in group 1 STIs were registered in $67.7 \%, \mathrm{p} 1.2>0.05$, the frequency of BV was 1.5 times higher $-28.4 \%$, p1.2<0.05.

4) The high occurrence of induced abortions, miscarriage, missed miscarriage is a manifestation that burdens reproductive history, was registered in women of group 1: single induced abortion was reported in $15.0 \%, 2$ times it took place in $15.7 \%$ (p1.2<0.05). The number of abortions per woman on average was the largest in group I $(\mathrm{p}<0.05)$.

5) The high frequency of all pelvic and abdominal surgery techniques, as well as gynecologic surgery was reported in women of group 1. Laparoscopies were previously performed in $59.8 \%$, laparotomies - in $62.2 \%$, at the same time in every fifth woman $(25.4 \%)$ surgical procedures were reperformed. Unilateral salpingectomy, due to ectopic pregnancy, was performed in every fifth woman $-25.4 \%$, bilateral in every tenth $-12.7 \%$. Fallopian tube removal, due to sactosalpinx, was performed in every fifth woman $-25.4 \%$, unilateral salpingectomy took place in $3.9 \%$ of patients.

6) The multiple factor analysis showed that the most significant risk factors of chronic endometritis in target groups are acute postabortal endometritis, $\mathrm{RR}=1.439$, $\mathrm{p}=0.029$ and postoperative peritonitis, provoked by the complications of appendectomy $-\mathrm{RR}=1.430, \mathrm{p}=0.084$.

7) The analysis of reproductive failures, as a risk factor of chronic endometritis in women of group 1 revealed the significant relative risk: with the past history of premature birth, $\mathrm{RR}=1.5, \mathrm{p}<0.001$, spontaneous miscarriage, $\mathrm{RR}=1.572, \mathrm{p}=0.001$. A higher relative risk of chronic endometritis was observed in missed miscarriage - $\mathrm{RR}=1,597, \mathrm{p}=0,001$.

Designing and adopting the program of preconception care and planning for pregnancy in women after ineffec- tive reattempts of using ART, with chronic endometritis as a primary disease, should be the top priority area of a health care system.

\section{CONCLUSIONS}

Statistical analysis of women's reproductive health after ineffective reattempts of using ART revealed that the high rate of fetal interventions, low rate of alternative and safe abortion methods are registered in these women, as well as the nonavailability of any system of health measures after reproductive failures. A significant increase in miscarriage at early stages takes place, as well as the absence of a tendency for preterm labor to decrease in the rate.

Maintaining women's reproductive health is a considerable medical and social issue, whose resolving depends on joint efforts of governmental and public entities, healthcare agencies and the population responsibility for own health. Designing and adopting the program of preconception care and planning for pregnancy in women after ineffective reattempts of using ART, with chronic endometritis as a primary disease, should be the top priority area of a health care system.

\section{REFERENCES}

1. Bochkov V.V., Plehanov A.N., Tsyidenova Ts.B. Hronicheskiy nespetsificheskiy endometrit: epidemiologiya, etiologiya, patogenez, faktoryi riska, diagnostika. [Chronic non-specific endometritis: epidemiology, etiology, pathogenesis, risk factors, diagnostics.] Herald of Buryat State University. 2015; 12:30 - 38. (in Russian).

2. Kozyireva E.V., Davidyan L.Yu., Kometova V.V. Hronicheskiy endometrit $\mathrm{v}$ aspekte besplodiya i nevyinashivaniya beremennosti. [Chronic endometritis in terms of infertility and non-gestation.] Ulyanovsky Medical-Biological Journ. 2017; 2:56 - 62. doi:10.23648/ UMBJ.2017.26.6218. (in Russian).

3. Plyasunova M.P., Hlyibova S.V. Hronicheskiy endometrit kak odna iz aktualnyih problem v sovremennoy ginekologii. [Chronic endometritis as one of the current problems in modern gynecology.] Vyatsky Medical Journal. 2013; 13:1 - 18. (in Russian).

4. Manuhin I.B., Sementsova N.A., Mitrofanova Yu.Yu., Livshits L.Yu. Hronicheskiy endometrit i nevyinashivanie beremennosti. [Chronic endometritis and lack of pregnancy.] Medical Board. 2018; 7:46-49. doi: 10.21518/2079-701X-2018-7-46-49. (in Russian).

5. Pluzhnikova T.A., Komarov E.K. Znachenie pregravidarnoy podgotovki zhenschin s nevyinashivaniem beremennosti v anamneze. [Importance of pregravitary training of women without pregnancy in anamnesis.] Obstetrics and Women's Diseases Journ. 2015. (in Russian).

6. Akopians A.L., Pisarska M.D., Wang E.T. The Role of Inflammatory Pathways in Implantation Failure:Chronic Endometritis and Hydrosalpinges. Semin. Reprod. Med. 2015; 33 (4): 298-304. doi:10.1055/s-0035-1554916.

7. Kitaya K., Matsubayashi H., Yamaguchi K. et al. Chronic endometritis: potential cause of infertility and obstetric and neonatal complications. Am. J. Reprod. Immunol. 2016; 75 (1): 13-22. doi: 10.1111/aji.12438.

8. McQueen D.B., Bernardi L.A., Stephenson M.D. Chronic endometritis in women with recurrent early pregnancy loss and/or fetal demise. Fertil. Steril. 2014; 101 (4): 1026-1030. doi: 10.1016/j.fertnstert.2013.12.031. 
9. Bouet P.E., El Hachem H., Monceau E. et al. Chronic endometritis in women with recurrent pregnancy loss and recurrent implantation failure: prevalence and role of office hysteroscopy and immunohistochemistry in diagnosis. Fertil. Steril. 2016;105(1):106-110. doi: 10.1016/j. fertnstert.2015.09.025.

10. Lyizikova Yu.A., Zinovkin D.A. Klinicheskaya harakteristika patsientok s besplodiem i immunogistohimicheskaya otsenka ekspressii Foxp3 i CD56 v endometrii. [Clinical characteristics of patients with infertility and immunogistically-chemical evaluation of expression of Foxp3 and CD56 in endometry.] Health and Environment. 2019; 1:35-40. (in Russian).

11. Farquhar C., Marjoribanks J. Assisted reproductive technology: an overview of Cochrane Reviews [Electronic resource]. Cochrane Database of Systematic Reviews. 2018;8. http://www. cochranelibrary.com.

12. Karpeev C.A., Tapilskaya N.I. Sostoyanie mikrobiotyi u patsientok s privyichnyim nevyinashivaniem beremennosti. [Microbiota in patients with a habitual lack of pregnancies.] Obstetrics and Gynecology of Saint Petersburg. 2018; 3(4): 8 - 13. (in Russian).

13. Kamath M.S., Bosteels J., D'Hooghe T.M. et al. Screening hysteroscopy in subfertile women and women undergoing assisted reproduction. Cochrane Database of Systematic Reviews. 2019:4. doi: 10.1002/14651858.CD012856.pub2.

\section{ORCID and contributionship:}

Tamara H. Romanenko: 0000-0003-0157-6223 ${ }^{A, E, F}$

Anastasiia D. Haiduk: 0000-0002-7242-2494 A,B,C,D

Svitlana V. Turbanist: 0000-0002-8733-1966 ${ }^{C, D}$

\section{Conflict of interest:}

The Authors declare no conflict of interest.

\section{CORRESPONDING AUTHOR}

Anastasiia D. Haiduk

Shupyk National Medical Academy of Postgraduate

Education of the Ministry of Health of Ukraine

9 Dorohozhytska St., 04112 Kyiv, Ukraine

tel: +380930096329

e-mail: haiduk.anastasiia@gmail.com

Received: 17.11 .2020

Accepted: 09.03.2021

A - Work concept and design, B - Data collection and analysis, C - Responsibility for statistical analysis,

D-Writing the article, $\mathbf{E}$-Critical review, $\mathbf{F}$ - Final approval of the article 